\title{
Lack of mutations of exon 2 of the MEN 1 gene in endocrine and nonendocrine sporadic tumors
}

\section{S.C. Costa ${ }^{1}$ \\ L.S. Nascimento ${ }^{1}$ \\ F.J. Ferreira ${ }^{1}$, P.S. Mattos ${ }^{2}$, \\ L.H. Camara-Lopes ${ }^{3}$ and L.S. W ard ${ }^{1}$}

\author{
Departamentos de ${ }^{1}$ Clínica M édica and ${ }^{2}$ Anatomia Patológica, \\ Faculdade de Ciências M édicas, U niversidade Estadual de Campinas, \\ Campinas, SP, Brasil \\ ${ }^{3}$ Departamento de Patologia, Hospital Sírio Libanês de São Paulo, \\ São Paulo, SP, Brasil
}

\section{Correspondence \\ L.S. Ward \\ Laboratório de Genética Molecular do Câncer \\ Departamento de Clínica M édica \\ FCM, Unicamp \\ 13081-970 Campinas, SP \\ Brasil \\ Fax: +55-19-289-4107 \\ E-mail: ward@ unicamp.br}

Research supported by FAPESP (No. 14097-1).

Received August 30, 2000 Accepted April 19, 2001

\section{Abstract}

In addition to the mutations that underlie most cases of the multiple endocrine neoplasia type 1 (MEN1) syndrome, somatic mutations of the MEN1 gene have also been described in sporadic tumors like gastrinomas, insulinomas and bronchial carcinoid neoplasm. We examined exon 2 of this gene, where most of the mutations have been described, in 148 endocrine and nonendocrine sporadic tumors. DNA was obtained by phenol/chloroform extraction and ethanol precipitation from 92 formalin-fixed, paraffin-embedded samples, and from 40 fresh tumor tissue samples. We used 5 pairs of primers to encompass the complete coding sequence of exon 2 of the MEN1 gene that was screened by the polymerase chain reaction-single-stranded conformation polymorphism (PCR-SSCP) technique in 78 sporadic thyroid cancers: 28 follicular adenomas, 35 papillary carcinomas, 14 follicular carcinomas, and 1 anaplastic thyroid carcinoma. We also examined 46 adrenal lesions ( 3 hyperplasias, 3 adenomas and 35 adrenocortical carcinomas, 2 pheochromocytomas, 2 ganglioneuroblastomas, and 1 lymphoma) and 24 breast cancers ( 6 noninvasive, 16 infiltrating ductal, and 2 invasive lobular tumors). The PCR product of 5 tumors suspected to present band shifts by SSCP was cloned. Direct sense and antisense sequencing did not identify mutations. These results suggest that the MEN1 gene is not important in breast, thyroid or adrenal sporadic tumorigenesis. Because the frequency of mutations varies significantly among tumor subgroups and allelic deletions are frequently observed at 11q13 in thyroid and adrenal cancers, another tumor suppressor gene residing in this region is likely to be involved in the tumorigenesis of these neoplasms.

Multiple endocrine neoplasia type 1 (MEN1) is characterized by the development of endocrine tumors of the parathyroid and pituitary glands, pancreas, and duodenum. Less frequently, other nonendocrine tumors such as lipomas and angiofibromas are asso-
Key words

- MEN 1 gene

- Sporadic tumors

- Thyroid

- Adrenal

- Breast ciated with MEN1 $(1,2)$. An increased incidence of thyroid neoplasms, leiomyomas, adrenocortical tumors, hepatic focal nodular hyperplasia, and renal angiomyolipoma has also been described in MEN1 families $(1,2)$. There are reports of MEN1 patients with 
complex series of tumors like esophageal leiomyomas, hepatic neuroendocrine metastasis, etc. $(1,2)$. The MEN1 gene has recently been identified and found to be widely expressed (3). Although the function of the nuclear protein encoded by the gene, called menin, remains unclear, it is recognized that the gene acts as a tumor suppressor gene since many of the identified menin germline mutations and mutations in sporadic tumors would lead to inactivation of menin or to Cterminally truncated proteins which would result in loss of repression of MEN1/JunD target genes (4).

Familial syndromes are a good starting point to look for tumor suppressor genes. The nonhereditary forms of the tumors present in these familial syndromes frequently present the same tumor suppressor gene inactivation, usually associated with some more gene mutations. Hence, a wide series of sporadic tumors has already been explored for MEN1 mutations. Inactivating mutations have been described in sporadic parathyroid adenomas $(21 \%)$, gastrinomas (33\%), bronchial carcinoid tumors (36\%), and occasionally, pituitary tumors (5-8). Because of the vast phenotype presentation of MEN1 syndrome, we decided to look for mutations of this gene in a wide series of sporadic tumors that are not directly related to the syndrome.

The institutional Committee on Ethics in Medical Research approved the study of a total of 148 patients ( 82 women and 66 men) who gave informed consent to participate. There were 121 endocrine tumors consisting of 78 sporadic thyroid cancers: 28 follicular adenomas, 35 papillary carcinomas, 14 follicular carcinomas, and 1 anaplastic thyroid carcinoma, and of 43 adrenal lesions: 3 hyperplasias, 3 adenomas, 35 adrenocortical carcinomas, and 2 pheochromocytomas. We also studied 27 patients with nonendocrine tumors consisting of 24 breast cancers ( 6 noninvasive, 16 infiltrating ductal, and 2 invasive lobular tumors) and of 2 ganglioneuroblastomas and 1 solid lymphoma of the adrenal gland. Patient age ranged from 4 to 78 years. Seventeen cases of adrenal tumors and 2 thyroid tumors were from children (4 to 16 years old). Forty samples were obtained at surgery, snap frozen and kept at $-80^{\circ} \mathrm{C}$ until processed. The other specimens were embedded in paraffin and selected from pathology archives. We were able to obtain normal tissue from the nonaffected lobe of 12 thyroid tumors. Tissue slices of lesions excised from the affected patients were reviewed by two of the authors (P.S.M. and L.H.C-L.) for confirmation of the diagnosis. Also, a section of each paraffin block was stained with hematoxylin-eosin and reviewed for diagnosis confirmation by the same pathologists. Tumoral tissue was carefully microdissected from the paraffin or the frozen blocks. The frozen tissues were ground under liquid nitrogen and DNA was extracted with the Trizol reagent (Life Technologies, Grand Island, NY, USA) according to manufacturer instructions. Five to 10 sections of $15 \mu \mathrm{m}$ were cut from each of the paraffinembedded tissue blocks and submitted to overnight digestion with proteinase $\mathrm{K}$. After phenol/chloroform extraction, the samples were precipitated in ethanol and then resuspended. The DNA concentration was determined by absorbance measurements at 260 / $280 \mathrm{~nm}$. All samples were stored at $-20^{\circ} \mathrm{C}$ until they were used.

We designed primers to encompass all exon 2 sequence because most of the mutations so far described in unrelated MEN1 patients with the same mutation concern this exon. The primers utilized are listed in Table 1.

Single-stranded conformational polymorphism (SSCP) analysis was performed by the Phast System-Pharmacia method (Pharmacia, Uppsala, Sweden) according to manufacturer instructions. Briefly, PCR was performed with 200 ng genomic DNA, 10 pmol of each primer, $100 \mu \mathrm{M}$ dNTPs, different $\mathrm{MgCl}_{2}$ concentrations for each pair of primers, $10 \mathrm{mM}$ Tris- $\mathrm{HCl}, \mathrm{pH} 9.0$, at $25^{\circ} \mathrm{C}, 50$ 
$\mathrm{mM} \mathrm{KCl}$, and $1 \mathrm{U}$ Taq polymerase in a final volume of $20 \mu \mathrm{l}$. Thirty-five cycles of denaturation $\left(94^{\circ} \mathrm{C}\right)$, annealing $\left(52^{\circ}\right.$ to $\left.62^{\circ} \mathrm{C}\right)$ and extension $\left(72^{\circ} \mathrm{C}\right)$ were conducted on an automated heat block (DNA thermal cycler, Perkin Elmer/Cetus, Norwalk, CT, USA). The reaction mixture was then diluted in DNA gel loading buffer, denatured and loaded onto the gel. Gels were stained with $\mathrm{AgNO}_{3}$ and photographed. All cases were screened at least twice by SSCP for the presence of an aberrant band in tumor DNA compared to normal DNA. Five PCR-amplified products presented shifts of bands on the SSCP gel and their DNA was reamplified by PCR. The PCR products were then cloned into a pGEM vector (Promega Corp., Madison, WI, USA). Finally, strand and antistrand DNA was run on the automated sequencer ABI 3776 (Perkin Elmer).

Figure 1 shows a representative example of PCR-SSCP analysis. We were unable to find any mutation among the screened cases. All five cases suspected to present band shifts on SSCP analysis revealed normal wildtype sequences.

The MEN1 gene encodes a 610-amino acid protein which has no homology to previously known proteins. The frequent findings of loss of heterozygosity ( $\mathrm{LOH}$ ) of 11q13 in MEN1-related tumors and their sporadic counterparts, together with the demonstration of somatic mutations in the latter group, imply that the gene is a tumor suppressor gene (8), which has been considered as a candidate for the genesis of adrenal and thyroid neoplasms. There are several studies using $\mathrm{LOH}$ technique indicating that 11q13 is involved in both of these neoplasms. With regard to the adrenals, $\mathrm{LOH}$ on chromosome 11 q13 has been observed in about $20 \%$ of adrenal adenomas but the prevalence of $\mathrm{LOH}$ increases up to $100 \%$ of the adrenal carcinomas investigated $(9,10)$. Overall, $\mathrm{LOH}$ was present in 23 of 44 (52\%) cases examined by different technical approaches (10). Concerning thyroid tumors, $11 \mathrm{q} 13$ has been found to be affected in 15 to $33 \%$ of the cases investigated using microsatellite markers (1113). Also 11q13 was found to be more frequently absent or inactivated in malignant thyroid phenotypes such as follicular and anaplastic carcinomas (11-13). In addition, LOH has been demonstrated in many nonMEN1-related tumors like breast cancer, where it has been suggested to harbor a tumor suppressor gene implicated in the transition from early preneoplastic lesions to invasive breast cancer (14). Recently, the MEN1 gene has been cloned from the 11q13

Table 1. Primers used to amplify the exon 2 sequence of the MEN1 gene. The sequence of the primer, the localization and length of the corresponding fragment and the annealing temperature of each primer are described.

\begin{tabular}{|c|c|c|c|}
\hline Primers & Sequence & Fragment & $\begin{array}{l}\text { Annealing } \\
\text { temperature }\end{array}$ \\
\hline A Sense & TTG CCT TGC AGG CCG CCG CC & $2254 \rightarrow 2456=202 \mathrm{bp}$ & $62^{\circ} \mathrm{C}$ \\
\hline A Antisense & TGG TAG GGA TGA CGC GGT TG & & \\
\hline B Sense & GGC TTC GTG GAG CAT TTT CT & $2411 \rightarrow 2612=201 \mathrm{bp}$ & $55^{\circ} \mathrm{C}$ \\
\hline B Antisense & CTC GAG GAT AGA GGG ACA GG & & \\
\hline C Sense & TTC ACC GCC CAG ATC CGA GG & $2564 \rightarrow 2759=195 \mathrm{bp}$ & $52^{\circ} \mathrm{C}$ \\
\hline C Antisense & TAA GAT TCC CAC CTA CTG GG & & \\
\hline H Sense & TTA GCG GAC CCT GGG AGG AG & $2195 \rightarrow 2421=226 \mathrm{bp}$ & $62^{\circ} \mathrm{C}$ \\
\hline H Antisense & TCC ACG AAG CCC AGC ACC AAG & & \\
\hline J Sense & СTG GCG GCC TCA ССТ АСT TTC & $2502 \rightarrow 2653=151 \mathrm{bp}$ & $62^{\circ} \mathrm{C}$ \\
\hline J Antisense & GGA GAC CTT CTT CAC CAG CTC AC & & \\
\hline
\end{tabular}

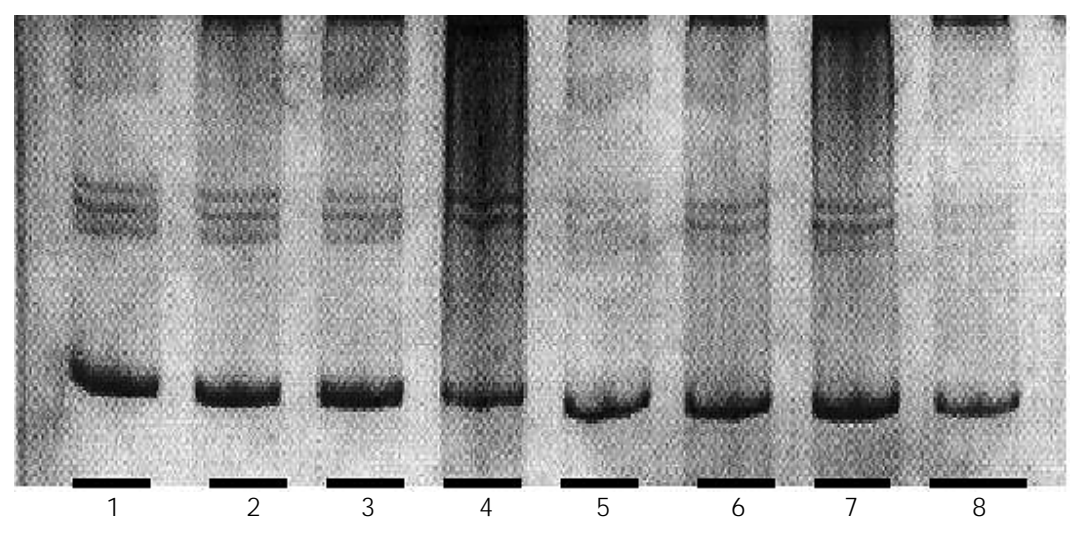

Figure 1. Gel of single-stranded conformation polymorphism (SSCP) analysis representative of our results for exon 2 in the multiple endocrine neoplasia type 1 (MEN1) gene screening for mutations. PCR products were loaded from normal tissue from the contralateral lobe of a thyroid follicular carcinoma (lane 1), from the thyroid follicular carcinoma of the same patient loaded on lane 1 (lane 2), from a thyroid papillary carcinoma (lane 3), adrenocortical carcinoma (lane 4), adrenocortical carcinoma (lane 5), adrenal adenoma (lane 6), breast infiltrating ductal cancer (lane 7), and thyroid papillary carcinoma (lane 8). 
region and somatic mutations have been demonstrated in MEN1 patients, who are characterized by a predisposition to develop parathyroid, pituitary and pancreas tumors and also adrenal cortex and thyroid lesions (1, $2,15)$.

In this context, we also screened a large series of endocrine and nonendocrine tumors for exon 2 of the MEN1 gene, where most of the mutations in sporadic tumors have been described (5-8). Our results support similar findings reported by Schulte et al. $(9,10)$ in adrenal lesions and by Nord et al. (12) in thyroid tumors. Among our breast tumors we also could not identify any mutation of exon 2 of the MEN1 gene. We were unable to find any literature reference to MEN1 gene studies in breast tumors. Similarly, the gene has also not been found to participate in the tumorigenesis of other nonendocrine tumors like lipomas and melanomas, although these tumors also do present high rates of $\mathrm{LOH}$ on $11 \mathrm{q} 13(16,17)$. The technique we used, SSCP, has a limited sensitivity and may have not detected small deletions involving the other exons of the gene we did not screen. A screening method for mutations that presents higher sensitivity, dideoxyfingerprinting, has detected many somatic and germline mutations distributed across the gene in familial MEN1 patients
(18). On the other hand, loss of function of tumor suppressor genes usually requires large deletions of chromosomal material. Therefore, our results add to other similar findings on thyroid and adrenal tumors, indicating the possible presence of another different tumor suppressor gene located in this chromosomal area but outside the MEN1 linkage interval $(9,10,12)$. Interestingly, a previous study of sporadic endocrine pancreatic tumors has also implicated the involvement of a second locus close to MEN1 (19). Another possibility is the existence of a "modifier" gene that may act in concert with the MEN1 gene altering the predisposition to tumorigenesis. Indeed, there is clinical and experimental evidence that one or more "modifier" genes may act in conjunction with the APC gene to alter predisposition to tumor formation at extracolonic sites such as the thyroid gland in patients with familial adenomatous polyposis (20).

In conclusion, by studying a large series of tumors, we demonstrated that exon 2 of the MEN1 gene is not involved in thyroid, adrenal or breast tumorigenesis. Our results and those reported by others suggest that a tumor suppressor gene in $11 \mathrm{q} 13$ other than MEN1 might be involved in the development of these cancers.

\section{References}

1. Marx SJ, Agarwal SK, Kester MB, Heppner C, Kim YS, Skarulis MC, J ames LA, Goldsmith PK, Saggar SK, Park SY, Spiegel AM, Burns AL, Debelenko LV, Zhuang Z, Lubensky IA, Liotta LA, EmmertBuck MR, Guru SC, Manickam P, Crabtree J , Erdos MR, Collins FS \& Chandrasekharappa SC (1999). Multiple endocrine neoplasia type 1: clinical and genetic features of the hereditary endocrine neoplasias. Recent Progress in Hormone Research, 54: 397-438.

2. Teh BT, Grimmond S, Shepherd J J Larsson C \& Hayward N (1995). Multiple en- docrine neoplasia type 1: clinical syndrome to molecular genetics. Australian and New Zealand J oumal of Surgery, 65: 708-713.

3. Chandrasekharappa SC, Guru SC, Manickam P, Olufemi SE, Collins FS, EmmertBuck MR, Debelenko LV, Zhuang Z, Lubensky IA, Liotta LA, Crabtree JS, Wang Y, Roe BA, Weisemann J, Boguski MS, Agarwal SK, Kester MB, Kim YS, Heppner C, Dong Q, Spiegel AM, Burns AL \& Marx S (1997). Positional cloning of the gene for multiple endocrine neoplasia-type 1. Science, 276: 404-407.
4. Gobl AE, Berg M, Lopez Egido J R, Oberg K, Skogseid B \& Westin G (1999). Menin represses J unD-activated transcription by a histone deacetylase-dependent mechanism. Biochimica et Biophysica Acta, 1447: 51-56.

5. Heppner C, Kester MB, Agarwal SK Debelenko LV, Emmert Buck MR, Guru SC, Manickam P, Olufemi SE, Skarulis MC, Doppman J L, Alexander RH, Kim YS, Saggar SK, Lubensky IA, Zhuang Z, Liotta LA, Chandrasekharappa SC, Collins FS, Spiegel AM, Burns AL \& Marx SJ (1997). Somatic mutation of the MEN1 gene in 
parathyroid tumours. Nature Genetics, 16: 375-378.

6. Zhuang Z, Vortmeyer AO, Pack S, Huang S, Pham TA, Wang C, Park WS, Agarwal SK, Debelenko LV, Kester M, Guru SC, Manickam P, Olufemi SE, Yu F, Heppner C, Crabtree J S, Skarulis MC, Venzon DJ , Emmert-Buck MR, Spiegel AM, Chandrasekharappa SC, Collins FS, Burns AL, Marx SJ , Lubensky IA, Asa SL \& Liotta LA (1997). Somatic mutations of the MEN1 tumor suppressor gene in sporadic gastrinomas and insulinomas. Cancer Research, 57: 4682-4686.

7. Debelenko LV, Brambilla E, Agarwal SK, Swalwell JI, Kester MB, Lubensky IA, Zhuang Z, Guru SC, Manickam P, Olufemi SE, Chandrasekharappa SC, Crabtree JS, Kim YS, Heppner C, Burns AL, Spiegel AM, Marx SJ , Liotta LA, Collins FS, Travis WD \& Emmert Buck MR (1997). Identification of MEN1 gene mutations in sporadic carcinoid tumors of the lung. Human Molecular Genetics, 6: 2285-2290.

8. Prezant TR, Levine J \& Melmed S (1998). Molecular characterization of the MEN 1 tumor suppressor gene in sporadic pituitary tumors. J ournal of Clinical Endocrinology and Metabolism, 83: 1388-1391.

9. Schulte $K M$, Heinze $M$, M engel $M$, Simon $D$, Scheuring $S$, Köhrer $K \&$ Röher HD (1999). MEN I gene mutations in sporadic adrenal adenomas. Human Genetics, 105: 603-610.

10. Schulte KM, Mengel $M$, Heinze $M$, Simon
D, Scheuring S, Köhrer K \& Röher HD (2000). Complete sequencing and messenger ribonucleic acid expression analysis of the MEN I gene in adrenal cancer. $\mathrm{J}$ ournal of Clinical Endocrinology and Metabolism, 85: 441-448.

11. Ward LS, Brenta G, Medvedovic M \& Fagin J A (1998). Studies of allelic loss in thyroid tumors reveal major differences in chromosomal instability between papillary and follicular carcinomas. J ournal of Clinical Endocrinology and Metabolism, 83: 525-530.

12. Nord B, Larsson C, Wong FK, Wallin G, Teh BT \& Zedenius J (1999). Sporadic follicular thyroid tumors show loss of a 200-kb region in 11q13 without evidence for mutations in the MEN1 gene. Genes, Chromosomes and Cancer, 26: 35-39.

13. Kitamura Y, Shimizu K, Tanaka S, Ito K \& Emi M (2000). Allelotyping of anaplastic thyroid carcinoma: frequent allelic losses on $1 q, 9 p, 11,17,19 p$, and 22q. Genes, Chromosomes and Cancer, 27: 244-251.

14. Chuaqui RF, Zhuang Z, Emmert Buck MR, Liotta LA \& Merino MJ (1997). Analysis of loss of heterozygosity on chromosome $11 q 13$ in atypical ductal hyperplasia and in situ carcinoma of the breast. American J ournal of Pathology, 150: 297-303.

15. European Consortium on MEN1 (1997). Identification of the multiple endocrine neoplasia type 1 (MEN1) gene. Human Molecular Genetics, 7: 1177-1183.

16. Schulte KM, Simon D, Dotzenrath C,
Scheuring S \& Röher HD (2000). Sequence analysis of the MEN1 gene in two patients with multiple cutaneous lipomas and endocrine tumors. Hormone and $\mathrm{Me}$ tabolism Research, 32: 76-79.

17. Boni R, Vortmeyer AO, Huang S, Burg G, Hofbauer $G \&$ Zhuang Z (1999). Mutation analysis of the MEN1 tumor suppressor gene in malignant melanoma. Melanoma Research, 9: 249-252.

18. Marx SJ, Agarwal SK, Kester MB, Heppner C, Kim YS, Emmert-Buck MR, Debelenko LV, Lubensky IA, Zhuang Z, Guru SC, Manickam P, Olufemi SE, Skarulis MC, Doppman J L, Alexander RH, Liotta LA, Collins FS, Chandrasekharappa SC, Spiegel AM \& Burns AL (1998). Germline and somatic mutation of the gene for multiple endocrine neoplasia type 1 (MEN1). J ournal of Internal Medicine, 243: 447-453.

19. Chakrabatti R, Srivatsan ES, Wood TF, Eubanks PJ, Ebrahimi AS, Gatti RA, Passaro E \& Sawicki MP (1998). Deletion mapping of endocrine tumors localizes a second tumor suppressor gene on chromosome band 11q13. Genes, Chromosomes and Cancer, 22: 130-137.

20. MacPhee M, Chepenik KP, Liddell RA, Nelson KK, Siracusa LD \& Buchberg AM (1995). The secretory phospholipase A2 gene is a candidate for the Mom1 locus, a major modifier of APC-induced intestinal neoplasia. Cell, 81: 957-966. 